\title{
Protection Of Intellectual Property Rights For Balinese Indigenous Industry In Cultural Tourism Business
}

\author{
Made Handijaya Dewantara \\ Politeknik Internasional Bali, Indonesia \\ Email: handi.dewantara@pib.ac.id
}

\begin{abstract}
This paper is written to identify and clarify some issues that occur in the protection of intellectual property rights for traditional products of Balinese indigenous industry, which are the main capital of cultural tourism business in Bali. In addition, this paper found out strategies that can be done to overcome the problem of intellectual property rights for Balinese indigenous people. Through library techniques and observation from July until December 2016, the research found several results. First, the obstacles in the protection of intellectual property rights of traditional societies, is because the products including tangible and traditional knowledge are generally verbal which is usually shown to the next generation, so it is difficult to register because to obtain the copyright of the work must be original and tangible. Meanwhile, to get the patent, the products must be new and inventive. Second, the strategies that can be done including IPR (Intellectual Property) socialization that implemented with priority system based on the objectives of interest, follow up cooperation that has been done, make IPR as compulsory subject in national curriculum, creates a special law to protect local indigenous people, and make association which specially take care of interest of creator, for example dance association, painters, sculptors, and artist association.
\end{abstract}

Keywords—Intellectual property, indigenous people, Bali, traditional works, tourism

\section{INTRODUCTION}

The progress of tourism business in Indonesia has a positive correlation with the advancement of science and culture. At the same time the problems associated with the advancement of science also take place simultaneously with the problems in the field of tourism. Bell (2011) in her article has mentioned that, IPR (intellectual property rights) issues are constantly evolving along with the development of science and technology. As the development of science and technology grows, there is some high needs for protection of intellectual property rights, which encourages the state to develop and update IPR regulations. Thus, it is also happening in the Indonesian tourism industry that relies on cultural development as the key for its progress.

The problem of tourism, especially in the field of IPR must be seen from the standpoint of forming the tourism itself. As the basis of the implementation of the tourism industry, culture plays an important role as well as transformed from the life of indigenous peoples (Twarog, 2004). The developing world community in the world is a transformation society from traditional society to industrial society. When globalization development and western culture then become the paradigm used in economic development of developing countries such as Indonesia, the economic system of the country concerned must directly or indirectly affect the lives of the people. People who still cannot enjoy the "cake" of tourism, especially those in the countryside or living outside the urban area, certainly face the consequences due to the application of Intellectual Property law.

Traditional artworks, traditional techniques that have long been "alive" in traditional societies, are regarded as an asset of economic value (Usman, 2002). This asset at the same time become as the main resource of the survival when the modern tourism went to the downturn. There are several cases of IPR that are well known when traditional knowledge is the object or source of legal disputes. For example: the issue of the cancellation of Shisedo's patent on traditional Indonesian ingredients, patent case of basmati rice between India and US multination corporation (MNC), tempe patent in U.S., etc. It is often used as a 'bullet' by developing countries in criticizing 'demand' of developed countries in the application of a stricter IPR system (comprehensive in protecting the interests of developed countries, such as: Integrated Circuit Layout Design, Trade Secret, protection of well-known brands of computer software, etc.). From some preliminary surveys, IPR was more developed to protect copyrights in music (with the Yayasan 
Karya Cipta Indonesia = YKCI which championed the copyrights of musicians), while copyrights for writers, artists and painters were far from being expected.

Agreement on Trade Related Aspects of Intellectual Property Rights (TRIPs) or approval of traderelated aspects of intellectual property rights have been ratified by Indonesia and realized through Law no. 7 of 1994. Therefore, Indonesia shall be subject to agreed agreements. One of the efforts undertaken by Indonesia in the field of IPR is to make improvements and add legislation so that in 2000, 2001, and 2002 the House of Representatives has passed some legislation in the field of IPR. These laws are:

1. Law no. 30 of 2000 on Trade Secrets;

2. Law no. 31 of 2000 on Industrial Design;

3. Law no. 32 of 2000 concerning Integrated Circuit Layout;

4. Law no. 14 of 2001 on Amendment to the Patent Law;

5. Law no. 15 of 2001 on Amendment of Brand Law;

6. Law No. 19 of 2002 on Amendment of Copyright Law.

Nowadays, the attention to intellectual property rights is growing, but there are also some criticisms of IPR. This paper attempts to analyze IPR in the context of human rights, which is related to the fulfillment of the rights to indigenous industry products, especially in Bali. In order to facilitate the understanding, this paper will focus on the concept of IPR protection which includes the nature, principles, and system of IPR, IPR arrangement as an effort to fulfill the right of science and technology, culture and art, and the problem and utilization of IPR as an effort to fulfill the right of science and technology, culture, and Indonesian art. Especially in the progress of the tourism industry, culture in the form of customs must be considered because it concerns the livelihood of many people.

Dilemmas always arise when there is a problem of IPR protection for traditional knowledge (traditional knowledges), especially in developing country (Hirimuthugodage, 2016). On one hand, developing country governments consider that traditional knowledges within their territory are an economic asset/capital especially for the tourism industry. For more details of the problem of IPR protection this traditional work then the problem in this paper is whether the traditional knowledge (traditional knowledge) of indigenous peoples, how the protection of traditional legal works and whether the barriers of IPR protection of indigenous peoples. By seeing these backgrounds, a question is finally formulated, how we could protect the intellectual property rights for indigenous works that produced by Balinese indigenous people to support cultural tourism business?

\section{METHODS}

In order to produce this paper, the research has been conducted from $1^{\text {st }}$ October 2016 until $1^{\text {st }}$ March 2017. The research was conducted to find the objective of this research, by using qualitative method, which relate to understand some aspects in social life, including how to protect the indigenous industry works. This method is chosen to generate words, opinions, and ideas from experts, indigenous people, and other informants, rather than numbers, as data for analysis. The main questions in this research finally addressed to some informants, including 30 respondents of indigenous people, 20 respondents from international visitors, 10 respondents from IPR experts, and some respondents who is coming from common people to complete the full perspective.

To generate data, some collecting methods have been chosen, including interview method, observation method, and focus group discussion method. The interview resembles everyday conversations, so that both researcher and respondents can be as confident as possible that the findings reflect what the research set out to answer, then reflecting the bias of the researcher. Group discussion was also chosen because it is seen more appropriate for some topics and some issues, including the protection of intellectual property rights. Seeing that the protection of intellectual property rights for indigenous people is very sensitive to discussed, researcher thinks that through group discussion, every respondent could possibly share their thoughts, their opinions, their ideas, and even their experiences. Through group discussion, it could tell this paper about the social structure of the community. It will also give more depth understanding, including how opinions and knowledges are formed in social context.

Finally, to generate more data, research was finally conducted by using observation through report, 
documents, and other oral data. To truly understand the complexities of intellectual property rights for indigenous people, direct participation in, and the phenomenon of interest, the observation was one of the alternative method. The documents also chosen because the written sources of data are highly more valid. The oral data is also chosen because many cultures are primarily oral rather than literary. Since the indigenous works in Bali is usually told through oral, then talking to the people informally would be an ideal way to listen their stories and experience, what they complained about, and what can or can't be said in various situation.

All the data that have been generated are finally reviewed and written through narrative analysis. Researcher was also ensuring that the validity (trustworthiness) of the findings could be maximized. After ensuring about the validity and clarify all the data, every data was finally checked and chosen to answer the research problem and make a conclusion.

\section{A. The Existence of Indigenous People}

It is mutually agreed that the tourism system in Indonesia uses the basis of its cultural diversity, as its primary source. It is undeniable that almost most of the noble culture in Indonesia is held and preserved by indigenous peoples. Indigenous and tribal peoples are a group of people bound by their customary legal order as citizens with a legal partnership because of their residence or based on genealogies (Lazar, 2002). Within the customary law community, the social and group character is an undeniable main feature, the common property still holds a very important role, that: in the concept of tradition, there is no view of the individual who in principle independent. In the individual concept, local tradition is an inseparable part of society. It exists and means as an individual because there is society. For customary law the community is the primary one.

The term of indigenous community is widely used in legislation (Janke, 2006). Nevertheless, there is not a single rule that provides an explanation of what the customary law community really means. The definition of indigenous peoples according to Mulya Lobis (2005) is "an orderly, permanent group of people, having their own power and wealth in the form of visible and invisible objects" (www.dephut.go.id). The existence of a diversity of cultural systems has been recognized as reflected in the motto "Unity in Diversity/Bhineka Tunggal Ika". Likewise, if we look at Article 18 of the 1945 Constitution; Article 5 of the Basic Agrarian Law (Law No. 5 Year 1960); and Article 6 of the Law on the Development of Population and Prosperous Family Development (Law No. 10 of 1992). The articles provide the legal basis for recognizing the existence of indigenous people.

Implicitly, it is known that 1945 Main Constitution recognizes the existence of 'traditional political entities' derived from the cultural system of various groups of society covered in the territory of the Republic of Indonesia. Where this recognition is of course not only limited to aspects of its institutional form, but also aspects of organizational structure, working mechanisms, regulations, and the various rights and obligations contained in the institutional system above. In addition, since the original arrangement can be regarded as a special area, the treatment of it must be special. That is, territorial entities and the institutional system governing them cannot be treated equally with other territorial unity territories that do not contain the original structure. In other words, implicitly, the arrangement implies the existence of autonomy or sovereignty of the original arrangement (WALHI, 1997).

\section{B. Traditional Knowledge of Indigenous People}

Indonesian tourism cannot be separated from the existence of Indonesian culture. Meanwhile, the existence of indigenous people who support the culture of Indonesia cannot be separated from the traditional knowledge owned by each indigenous people themselves. Traditional cultures, however, are often incapable of being accommodated by the protection of intellectual property rights, so there is often an issue of intellectual property theft of indigenous peoples. An interesting issue and currently developing within the scope of intellectual property rights assessment (IPR) is the legal protection of intellectual property generated by indigenous peoples or traditional societies (McCoy, 2011). One of the intellectual property of indigenous people or traditional society is traditional knowledge system. Traditional knowledge, according to WIPO, the definition is: "Tradition based literary, artistic or scientific works, performances, inventions, scientific discoveries, designs, marks, names, and symbols, undisclosed information, and, all other tradition-based innovations and creations resulting from Intellectual activity in the industrial, scientific, literary or artistic fields.

The problems that always occur when protecting traditional knowledge must be identified first. 
According to the research from Nicholas (2009), there are 4 (four) categories of issues identified in IPR protection for traditional knowledge: 1) Terminological and conceptual issues; 2) Standard concerning the availability, scope, and use of intellectual property rights in traditional knowledge; 3) Certain criteria for the application of technical elements standards, including the legal criteria for the definition of the prior art and administrative issues related to the examination of patent application; And 4) Enforcement of rights in traditional knowledge.

The uniqueness of the character of the traditional knowledge itself can be a factor causing the problems that pervade the arts of indigenous peoples. As is known many of the various traditional knowledge both in the form of folk art, and traditional technologies are not known origin (who created, etc.) or commonly called anonymous. A knowledge or traditional work is knowledge that is spoken by hereditary (intergeneration), and mostly in an unwritten manner. Traditional knowledge also lives in a society that embraces communalism. This leads to traditional knowledge at the level of indigenous peoples being inclusive. All parties can take advantage of it for free.

\section{Strategy of IPR Protection of Traditional Works}

Countries that are successful in tourism, such as France, Italy, China, Japan, and even Indonesia recently often questioned IPR theft of their traditional works. The problem of traditional knowledge is a very important aspect championed by countries that have potential in this field to get legal protection. However, theoretically traditional knowledge itself is very possible to be protected. There are two mechanisms that can be done within the framework of providing traditional knowledge protection, namely: First; Protection in the form of law and protection in non-legal form. Form of protection in the form of law, namely the effort to protect traditional knowledge through a binding legal form, such as; Intellectual property law, regulations governing genetic resources, particularly traditional knowledge, contracts and customary law. The protection of traditional knowledge through the Intellectual Property Rights regime is intended to protect intellectual property rights. The purpose of this effort is: to encourage the creation of new intellectual works (for example based on copyright law, patents and industrial design), to provide openings of new intellectual works (based on patent law and industrial design), facilitate Market order through eraser; Confusion (policies based on brand law and geographical indications), and unfair competition actions, and protecting the disclosure of information from unauthorized users.

The second strategy is to provide protection in the form of non-legal is protection given to nonbinding traditional knowledge, including code adopted through international, government and nongovernment organizations, professional and private sector. Other protections include compilation of inventions, registrations, and databases of traditional knowledge.

In Indonesia, legal protection against traditional knowledge, whether explicitly or implicitly, is contained in: a. Copyright Law (Law No. 12 of 1997 concerning Amendment to Law Number 6 of 1982 regarding Copyright as Has Been Amended by Law Number 7 of 1987), Article 10, and Article 11 Paragraph (1); And b. Law on Plant Variety Protection / PVT (Law No. 29/2000 on Plant Variety Protection), Article 7. Protection of traditional knowledge in Indonesia is also contained in the regulations of laws and regulations other than the Intellectual Property Law. In Law No. Law No. 5 of 1994 on the ratification of the United Nations Convention on Biodiversity (UNCBD), Article 8 Sub-Paragraph (1) UNCBD, stipulates that signatories to the Convention shall respect, protect, and retain local, indigenous and local knowledge, innovations and practices. Reflects a traditionally traditional lifestyle, consistent with the conservation and sustainable use of biological diversity and promotes its wider application with the consent and involvement of the owner of such knowledge, innovation and practice and encourages fair sharing of benefits resulting from the utilization of knowledge, innovations and such practices.

\section{Obstacles to Protect the Intellectual Property of Indigenous People}

It is not an easy thing to give protection to the intellectual property law of indigenous peoples. Indigenous and rural communities, not only in Indonesia, often protest that IPR law only aims to protect the creation and investment of developed countries but fails to protect their traditional activities and knowledge. This is understandable because the IPR system based on western liberal ideas on the ownership of various intellectual property is more profitable for art products and western invention. Since many traditional works and knowledge created or derived from indigenous peoples have become popular all over the world (art treasures) and sometimes necessities (medicine), the international trade in intellectual property is valued up to billions of dollars each Years around the world. However, most of the revenue 
from the sale is ultimately in the hands of companies from outside the original area of the work, and more often are foreign companies.

There are two reasons why most indigenous peoples cannot accept this unpleasant fact, namely: 1) Authors, artists and creators from traditional societies rarely receive adequate financial rewards for intellectual property in the form of exploited traditional knowledge. 2) Unauthorized use of these exploited works of traditional knowledge sometimes offends people who create such traditional knowledge. For example, the commercialization of sacred works that are forbidden religion or custom. The failure of the intellectual property system to protect traditional knowledge and work begins with a view that is more concerned with protecting the rights of individuals rather than the rights of the community. IPR can usually be owned by a person or group of individuals who can be known (both ordinary people or companies). Requirements that must be met to obtain individual property rights reflect the basic beliefs that are usually regarded as being observed by western countries.

\section{E. Pros and Cons of IPR Protection of Indigenous Peoples}

Despite frequent internal and external barriers, IPR protection of indigenous peoples should be a priority, especially in sustaining the national tourism industry. Moreover, to ensure the sustainability of this tourism industry. Some of the strategies that have been implemented must be re-enforced, and support strategies must be prepared. As outlined in the introduction, that because of ratification of GATT (including TRIPs) Indonesia shall be obliged to conform the national legislation on IPR in full. TRIPs contain high regulatory standards and rigorous enforcement mechanisms. High default settings, for example:

1. The copyright protection of the old computer program must be not less than 50 years.

2. The rights granted in patents and marks are not limited to the right to use, rent, sell or authorize others to use (prohibit others from using without consent), but include the right to prohibit the import of products that protect patents / Concerned by others who are not eligible.

3. Patent protection must be given for 20 years.

4. Introduction of reversed evidentiary system in the framework of protection against patent enforcement of any process even in civil cases.

5. It is mandatory to provide sui generis protection against technological invention in the field of crop varieties. The strict enforcement mechanism according to TRIPs, which involves customs, means granting the right to copyright holders, patents, trademarks to request customs authorities not to permit / retain imported goods at ports if law enforcement has sufficient data to suspect that goods - the import is a violation of IPR.

But if examined in depth there is an inter-business and human rights interests that ultimately lead to improving the quality of human welfare (human dignity). The losses to be suffered may be too great to bear if deliberately about human rights are violated, and these losses can mean the company's breakdown, the damage to the company's reputation, or even the contract with the company, especially the companies engaged in the tourism industry. However, it should be anticipated also the emergence of criticisms against IPR, among others:

1. IPR can create monopoly resulting in high prices

2. Royalties will lead to higher prices and prevent the flow of knowledge

3. IPR causes allow companies not to fully utilize their inventions.

Intellectual property rights arrangements through TRIPs make a difference about whether IPR is in the interest of developing countries. According to Ceunfin from the perspective of developing countries, it is often assumed that the renewal of IPR law will be enjoyed by intellectual property exporting countries, developing countries usually only act as consumers rather than intellectual property producers so they do not feel the need to protect them strictly. Intellectual property is also seen as an expensive barrier (sometimes the basis of prohibition) in the transfer of western technology that the developing country needs to promote economic development and social welfare. The following will outline the opinions of developing countries on the reform of the IPR arrangements.

1. Influence on Foreign Investment

In relation to efforts to increase foreign investment in Indonesia, the scholars have expressed a convincing opinion that the enhancement of IPR protection will only help attract foreign investment with 
the most sophisticated technology. Since the base of most industries in Indonesia today-the agriculture, manufacturing, and services sectors - is not so much affected by the existence of IPR.

\section{Increase in Costs.}

Strict IPR arrangements will raise high costs. This has caused most Indonesians will not be able to or do not have enough purchasing power given the per capita income of the Indonesian people has decreased by almost $50 \%$ to less than US \$ 600 per year since the economic crisis.

\section{Piracy as a Source of Livelihood}

Significantly rising unemployment in Indonesia since the economic crisis, in addition to weak law enforcement, has made the piracy industry grow rapidly and create jobs as makers, distributors and retailers.

\section{The Effect of Intellectual Property Rights for Local Inventions}

It is alleged that the increased protection of IPR in Indonesia will not have much effect for the growth of new innovations in the country due to lack of funds owned by the private sector, as well as experts. Indonesia's scientific ability is very low, there are only 181 scientists and engineers for everyone million inhabitants, and only accounted for $0.01 \%$ of the total published scientific work of the world. In 2001 the government only allocated $0.16 \%$ of gross domestic product for science and technology sector, down $0.2 \%$ from 2000 .

\section{Takeover of Traditional Works and Knowledge}

Most Indonesians began to realize that IPR may not be able to protect traditional creations and traditional knowledge, in fact helping to take over the work and knowledge by companies, both Indonesian companies and foreign companies. Foreigners visiting rural Indonesia, researching and extracting genetic samples from animals and plants and then patenting them and profiting significantly. The State Minister for the Environment has described "biological piracy" as a new form of imperialism.

\section{IP law and customary law}

The greatest denial of IPR based on economic and social variables is a concept that has long been recognized by most Indonesians in accordance with customary law. IPR is foreign to the beliefs underlying customary law. Many of the abstract constructs common to the western legal system are not recognized by most customary law. One of them is the difference between tangible and intangible property. Customary law is based on concrete, real and visible concrete justice construction so as not to recognize the sale of intangible goods. Moreover, the principle of customary law which is universal and perhaps most fundamental is that customary law is more concerned with society than individuals. With the above reasons, many people are pessimistic about the renewal of the IPR system, many argue that Indonesia is not the time to apply IPR because the rate of economic growth and technology is not as advanced as other countries that have been taking off to industrial society. There are three negative impacts caused by IPR system:

a) The boundary monopoly right of IPR system creates high cost

b) Companies that own IPR do not exploit their inventory fully to the public because they keep IPR for business purposes.

c) IPR systems can hinder the spread of knowledge.

Although there are objections and criticisms against IPRs and the possible negative impact of the IPR system of being a priori against the existence of IPR is not wise, because:

a) Losses resulting from the implementation of the IPR system are temporary and take place in the short term. If Indonesia can optimize the utilization of IPR negative impact will be a benefit for the Indonesian nation.

b) Refusing IPR's presence will bring harm to Indonesia as all WTO member countries have agreed to implement IPR with all its consequences. The consequence of not signing or ratifying it is that it will be alienated from international relations and global commerce.

c) Refusing the existence of IPR is also a futile act because IPR has become an international 
standard. Indonesia has ratified TRIPs through Law No. 7 of 1994 which brings the consequence that Indonesia should implement IPR properly without exception.

Responding to the objection to the renewal of the IPR arrangement and the negative impact it will cause, Tim Lindsey put forward several solutions to the utilization of IPR for development purposes in Indonesia:

a) IPR Socialization is implemented with priority system based on the target of interest, for enforcement of IPR target is law enforcement officer, for propagation of IPR, target is industry especially small and medium industry and university.

b) Following up the cooperation that has been done, for example cooperation of IPR office with university through establishment of IPR Management Center (IPR Clinic).

c) It is necessary to think about making IPR as compulsory subject in the national curriculum not only in Faculty of Law but also faculty of exact sciences.

d) Special associations need to be taken care of the interests of the creators, such as dance associations, painter associations, sculptors, and so forth.

\section{CONCLUSIONS}

There are two mechanisms that can be done within the framework of protecting traditional knowledge, namely protection in the form of law, that is through international legislation and convention and protection in the form of non-law, namely protection given to non-binding traditional knowledge, including code of Conduct adopted through international, governmental and non-governmental organizations, professional societies and the private sector.

Intellectual property rights arrangements in Indonesia are hierarchically contained in the Constitution and other laws and regulations. Therefore, Indonesia ratified GATT including TRPs containing high standards and strict mechanisms, IPR legislation in Indonesia must continue to be adjusted with TRIPs. Currently, Indonesia is allegedly not ready to implement TRIPs, there is a negative view on IPR, that is the possibility of losses that will arise in the application of IPR in Indonesia, among others related to the high cost that will arise, no significant influence on the entry of foreign investment into Indonesia, and Possible "biological piracy" to Indonesia's natural resources. However, being a priori for the renewal of the IPR system will cause some losses. Therefore, Indonesia should take advantage of IPR for development purposes, among others, by setting targets and priorities for IPR exploitation, as well as improving law enforcement for certain fields.

Through this paper, we would like to give suggestions such as the need to optimize IPR for the welfare of the Indonesian nation, by preparing the priority measures of IPR enforcement in certain fields specially to save knowledge assets, culture, crop varieties, natural resources, and geographical indications Owned by traditional society not to be exploited by company or foreign citizen. The need to establish an institution that serves as a mediation in the IPR settlement process, so that the dispute resolution is not only done through the court (litigation), but also through non-court (non-litigation) efforts, among others through mediation. And finally, the government in cooperation with universities should encourage and encourage the establishment of institutions (such as IPR clinics), to carry out advocacy functions that help inventors and creators in the IPR registration process to facilitate the public to register IPR. Understanding of IPR needs to be invested early on, therefore the IPR's content / values need to be included in textbooks / textbooks at all levels of formal education. 


\section{REFERENCES}

Bell, Catherine. 2011. Intellectual Property and Indigenous Cultural Heritage: Ongoing Research and Issues of Reform. Osgoode Hall Law School of York University.

Ceunfin, Frans ( editor). 2004. Hak-hak Asasi Manusia Pendasaran dalam Filsafat Hukum dan Filsafat Politik. Maumere : Ledalero.

Hirimuthugodage, Dilani. 2016. Intellectual Property Rights - A Tool for Enhancing Ecotourism in Srilanka. South Asia Monitor 12 May 2016.

Janke, Terri, and Quiggin, Robynne. 2006. Indigenous Cultural and Intellectual Property: The Main Issues for Indigenous Arts Industry in 2006. Aboriginal and Torres Strait Islander Arts Board Australian Council: 10 May 2006.

Lazar,Alex Seru. 2002. Tanah Suku di NTT. Pos Kupang. http://www.indomedia.com Lokakarya Kepentingan Negara Bekembangan Terhadap Hak Atas Indikasi Geografis Sumber Daya Genetika dan pengetahuan Tradisonal, http://www.hukumonline.com

McCoy, Melody L. 2011. A Primer on Tribal Cultural and Intellectual Property Rights. American Indian Alaska Native Tourism Association Conference September 13-14, 2011.

Mulya Lubis, Todung. 2005. Jalan Panjang Hak Asasi Manusia. Jakarta : Gramedia Pustaka Utama.

Nicholas, George; Bell, Catherine; Bannister, Kelly; Ouzman, Sven; Anderson, Jane. 2009. Intellectual Property Issues in Heritage Management. Left Coast Press Inc. Heritage Management, Volume 2, Issue 2, Fall 2009.

Twarog, Sophia. 2004. Protecting and Promoting Traditional Knowledge : Systems, National Experiences, and International Dimensions. United Nations Conference on Trade and Development. UN Report 2004.

Usman, Rachmadi. 2002. Hukum Hak atas Kekayaan Intelektual : Perlindungan dan Dimensi Hukumnya di Indonesia. Bandung : Alumni.

World Intellectual Property Organization. 2014. Intellectual Property and Tourism: Supporting Development Objectives and Protecting Cultural Heritage In Egypt And Other Developing Countries. Committee on Development and Intellectual Property (CDIP). Thirteenth Session. Geneva, May 19 to 23, 2014.

\section{Law as References}

Republik Indonesia. 1945. Undang-Undang Dasar

Republik Indonesia. 1960. Undang-Undang No. 5. Pokok-pokok Agraria

Republik Indonesia. 1992. Undang-Undang No.10. Perkembangan Kependudukan dan

Pembangunan Keluarga Sejahtera.

Republik Indonesia. 1997. Undang-Undang No. 12. Hak Cipta.

Republik Indonesia. 2000. Undang-Undang No. 29. Perlindungan Varietas Tanaman

Konvensi Keanekaragaman Hayati (United Nation Convention on Biodiversity /UNCBD) Konferensi Diplomatik Stockholm. 1967. 